\title{
A Potential Constitutional Moment for the European Rule of Law: The Importance of Red Lines
}

\author{
Armin von Bogdandy, Piotr Bogdanowicz, Iris Canor, Giacomo Rugge, \\ Matthias Schmidt, and Maciej Taborowski
}

\begin{abstract}
Contents

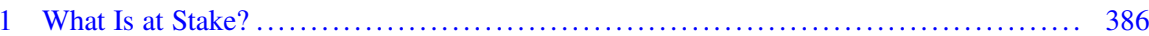

2 Operationalizing the Value of the Rule of Law $\ldots \ldots \ldots \ldots \ldots \ldots \ldots \ldots \ldots \ldots \ldots \ldots \ldots \ldots$

3 The Political Branch in Troubled Waters ................................... 389

4 The Judicial Branch: 'I Love You, Like I Love Ireland' .......................... 392

5 From the Maastricht Urteil to the $L M$ Case .................................. 396

6 Conclusion ........................................................... 399

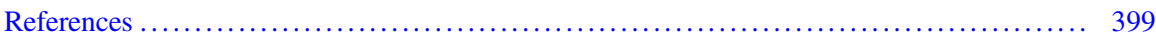

\begin{abstract}
This contribution deals with the current European rule of law crisis. It does so by analyzing the recent CJEU's judgment in re $L M$ and by considering its possible ramifications for the future of the rule of law in the EU. In particular, it is argued that, as a result of this judgment, the European rule of law as provided for by Art. 2 TEU has become a legally enforceable value. The CJEU has indeed made clear that this value features a set of minimum standards that the Member States cannot bluntly disregard. In the present context, which is characterized by the inaction of the supranational and national political institutions, a prominent role in safeguarding a liberal understanding of the European rule of law is played by the
\end{abstract}

An earlier version has been published in the Common Market Law Review.

A. von Bogdandy $(\bowtie) \cdot$ G. Rugge $\cdot$ M. Schmidt

Max Planck Institute for Comparative Public Law and International Law, Heidelberg, Germany

e-mail: sekreavb@mpil.de; rugge@mpil.de; mschmidt@mpil.de

P. Bogdanowicz $\cdot$ M. Taborowski

Faculty of Law and Administration, University of Warsaw, Warsaw, Poland

e-mail: p.bogdanowicz@wpia.uw.edu.pl; maciej.taborowski@brpo.gov.pl

I. Canor

School of Law, Zefat Academic College, Sefad, Israel

School of Law, College of Management, Rishon Le Zion, Israel

e-mail: canor@colman.ac.il 
entire European judiciary (the so-called 'Gerichtsverbund'), including national courts and tribunals.

\section{What Is at Stake?}

The Union's 'rule of law crisis' is a multi-faceted phenomenon. ${ }^{1}$ Of particular concern are Member States where ruling majorities wilfully uproot the separation of powers. The current focus is very much on Poland. The Polish government has taken extensive measures that have undermined the independence of the Constitutional Tribunal. It has strengthened its influence on the National Council of the Judiciary, which selects the judges. It has dismissed more than 150 (out of 700) presidents and vice presidents of ordinary courts. It has forced almost $40 \%$ of Supreme Court judges to retire. ${ }^{2}$ It has raised the overall number of Supreme Court judges, thereby creating the need for up to 70 new nominations. It has established a new disciplinary chamber as well as an extraordinary appeals procedure before the Supreme Court, which has the potential to subdue independentminded judges. ${ }^{3}$ Yet other Member States should not be forgotten either, such as Hungary. The latter is even said to have become a rather hopeless case-with some involuntary help from Brussels, e.g., through its funds. ${ }^{4}$ Hopefully, the recent adoption by the European Parliament of a reasoned proposal under Article 7 (1) TEU will help improve the situation in Hungary. But, should these authoritarian measures remain unopposed, it will be hard to argue in the future that they are at odds with the European values as enshrined in Article 2 TEU. ${ }^{5}$

European institutions have started to react far more determinedly than in the Hungarian case. This is to be welcomed. At the same time, the European reactions raise the stakes dramatically. We might even witness a 'constitutional moment'. This term indicates a situation that deeply impacts on the future path of a constitutional

\footnotetext{
${ }^{1}$ Editorial Comments (2015), pp. 619, 625-627; Editorial Comments (2016), p. 597; Editorial Comments (2017), p. 1309; on the academic debate Bonelli (2017), p. 793.

${ }^{2} \operatorname{COM}(2017) 835$ final, 'European Commission, Reasoned Proposal in accordance with Article 7 (1) of the Treaty on European Union regarding the rule of law in Poland: Proposal for a Council Decision on the determination of a clear risk of a serious breach by the Republic of Poland of the rule of law', at p. 21, para. 116.

${ }^{3}$ Act on the Supreme Court of 8 December 2017, Journal of Laws (2018), item no. 5.

${ }^{4}$ For a dire picture, Charlemagne, The Economist, April 5, 2018. Halmai (2018), p. 85. See also European Parliament, Committee on Civil Liberties, Justice and Home Affairs, 25th June 2018 (Result of roll-call votes), http://www.europarl.europa.eu/committees/en/libe/votes-in-committee. html.

${ }^{5}$ See for a comprehensive description Matczak (2018); 'Opinion on the Draft Act amending the Act on the National Council of the judiciary; on the Draft Act amending the Act on the Supreme Court, proposed by the President of Poland, and on the Act on the organisation of ordinary courts', adopted by the Commission at its 113th Plenary Session (Venice, 8-9 December 2017), http://www.venice. coe.int/webforms/documents/default.aspx?pdffile $=$ CDL-AD(2017)031-e.
} 
order without formally amending it. ${ }^{6}$ At issue is whether illiberal democracies become part of the European public order as laid out in Article 2 TEU, or are opposed by it. In any event, the consequences could be truly far-reaching. In the first case, the conventional self-understanding of Europe cannot be maintained any longer, because the European rule of law would cover - and thus legitimize-what is currently happening in Poland and Hungary. This would have tremendous implications, for example for the European stance towards critical developments in other Member States or the Union's external policy (Turkey!). In the second case, the European rule of law would be supplemented by 'red lines'. That would also amount to a 'constitutional moment' because it would add substance and bite to the European values.

To advance the second case, the European institutions are to be commended for reacting fiercely. The Commission's actions, in particular its Article 7 TEU proposal, merit support, also for good legal reasons. At the same time, much will depend on the judicial branch. It is indeed no coincidence that a first, important opportunity to draw such red lines has arisen in the context of legal proceedings, more precisely in the context of what is now known as the $L M$ case. $^{7}$ Initiated by the Irish High Court through a request for a preliminary ruling, this case concerned the interpretation of Article 1(3) of the European Arrest Warrant Framework Decision (hereinafter: EAW Framework Decision). More specifically, the Irish judge asked whether that provision of the Framework Decision could be so construed as to exclude the execution of a EAW in case of "cogent evidence that conditions in the issuing Member State are incompatible with the fundamental right to a fair trial because the system of justice itself in the issuing Member State is no longer operating under the rule of law'.

This case will be analysed in greater detail in what follows. It has to be said, though, that no European political measure or judicial decision can, by or of itself, restore the separation of powers in a Member State. They can only contribute to Polish self-healing through its internal constitutional process. However, their importance is not limited to this, as they are crucial for upholding European liberal constitutionalism in the rest of the Union. In fact, it is in this light that the $L M$ case must be read. But before examining the case, some introductory remarks are in order.

\footnotetext{
${ }^{6}$ Ackerman (1991), Vol 1, 6. Note that the original articulation of this term by Ackerman has a more specific meaning. For further analysis, Klarman (1992), pp. 759-797.

${ }^{7}$ Case C-216/18 PPU, Reference for a preliminary ruling from the High Court (Ireland) made on 27 March 2018 - Minister for Justice and Equality v LM, (pending), http://www.courts.ie/ Judgments.nsf/0/FD843302847F2E228025825D00457F19. This case is based on a referral from the Irish High Court 2013295 EXT;2014 8 EXT; 2017291 EXT The Minister for Justice and Equality v. Celmer, [2018] IEHC 119, http://www.courts.ie/Judgments.nsf/0/ 578DD3A9A33247A38025824F0057E747. See also Case C-216/18 PPU, Reference for a preliminary ruling from the High Court (Ireland) made on 27 March 2018 - Minister for Justice and Equality v LM, Opinion of Advocate General Tanchev, ECLI:EU:C:2018:517. 28th June 2018.
} 


\section{Operationalizing the Value of the Rule of Law}

By now, much has happened to operationalize-i.e., interpret, apply and even impose-the rule-of-law value. Confuting many who consider the rule-of-law value of Article 2 TEU an all too vague political statement, the guardians of the Treaties have developed it in a way that allows for a juridical assessment of Member States' activities. To be clear, the institutions have not set out to demarcate the value by creating definitions that can be applied in a formalistic manner, but have rather linked the value of the rule of law to well-established principles. Their application requires much contextualization and circumspection and will inevitably contain political, i.e., discretionary, evaluative and opportunistic, elements. But that is the path of the law, in particular when it comes to 'constitutional moments'.

A ground-breaking contribution to the operationalization of the rule-of-law value can be found in the CJEU's recent decision in the case of Associação Sindical dos Juizes Portugueses (ASJP). Its interpretation of Article 19 TEU covers the institutional dimension of domestic judicial independence. ${ }^{8}$ The European rule of law has thus become justiciable vis-à-vis the Member States. ${ }^{9}$ The Commission contributes to this development by compiling relevant principles into a sensible whole, in particular in its Rule of Law Framework. ${ }^{10}$ It relies on many sources: the Court's rulings, but also decisions and opinions of other institutions, in particular the European Court of Human Rights and the European Commission for Democracy through Law (the Venice Commission). Such a broad spectrum contributes significantly to the legitimacy of its endeavour.

The Commission's Rule of Law Framework is an important step with regard not only for the interpretation but also, possibly, for the normativity of the rule of law. Although it shows some weaknesses, for example by making it almost indistinguishable from the values of democracy and human rights, it seems a convincing operationalization that is in tune with the acquis of European public law. The Commission has reiterated the Framework's interpretation in its Reasoned Proposal under Article 7(1) TEU regarding the Rule of Law in Poland. ${ }^{11}$ Moreover, it referred to the rule-of-law value in its 2018 Justice Scoreboard for 'monitoring of justice reforms at EU level' as well as in its last Country Report on Poland under the European Semester. ${ }^{12}$ The Commission's recent regulation proposal on 'the

\footnotetext{
${ }^{8}$ CJEU, Case C-64/16, Associação Sindical dos Juizes Portugueses, ECLI:EU:C:2018:117.

${ }^{9}$ CJEU, Case C-477/16 PPU, Kovalkovas, ECLI:EU:C:2016:861; Case C-452/16 PPU, Poltorak, ECLI:EU:C:2016:858.

${ }^{10} \mathrm{COM}(2014) 158$ final/2, 'European Commission, Communication from the Commission to the European Parliament and the Council: A new EU framework to strengthen the rule of law' p. 4, and Annex I.

${ }^{11}$ Supra note 2, p. 1, para. 1.

${ }^{12}$ SWD(2018) 219 final, 'Commission Staff Working Document, Country Report Poland 2018 accompanying the document Communication from the Commission to the European Parliament, the Council, the European Central Bank and the Eurogroup: 2018 European Semester: Assessment
} 
protection of the Union's budget in case of generalised deficiencies as regards the rule of law in the Member States' even provides a definition for the threshold of 'generalised deficiencies' of the rule of law. ${ }^{13}$ Operationalization can also be helped by a newly suggested 'Justice, Rights and Values' Fund with a total volume of 947 million euros. ${ }^{14}$ Already in force-albeit not yet enforced-is the Union's Regulation on European Political Parties, which permits reviewing whether a European party complies with Article 2 TEU. ${ }^{15}$

Notwithstanding a number of doctrinal issues that remain open, at least the basis for legally assessing Member States using the rule-of-law value is now fairly wellestablished. From the Polish 'White Paper on the Judiciary', one can deduce that not even the Polish government puts that into question, since it defends its measures on the merits of the European rule of law. ${ }^{16}$ The impressive rebuttal of that 'White Paper' by the Polish Judges Association as well as by the Polish Supreme Court also shows a well-established juridical link between the vague rule-of-law value and crucial features of the domestic judiciaries. ${ }^{17}$ The European rule of law has thus become an operational principle in European political and legal controversies.

\section{The Political Branch in Troubled Waters}

Opposing the Polish measures is extremely sensitive because it implies going against a democratically elected government that is transforming basic features of its constitutional order. For that reason it is to be welcomed that the European political

of progress on structural reforms, prevention and correction of macroeconomic imbalances, and results of in-depth reviews under Regulation (EU) No 1176/2011', p. 3, 29.

${ }^{13} \mathrm{COM}(2018) 324$ final, 'European Commission, Proposal for a Regulation of the European Parliament and of the Council on the protection of the Union's budget in case of generalised deficiencies as regards the rule of law in the Member States', at Art. 2(b).

${ }^{14} \operatorname{COM}(2018) 321$ final, 'Annex to the Communication from the Commission to the European Parliament, the European Council, the Council, the European Economic and Social Committee and the Committee of the Regions, A modern budget for a Union that protects, empowers and defends: The multiannual financial framework for 2021-2027', p. 48.

${ }^{15}$ OJ 2011 L 317/1, 'Regulation (EU, EURATOM) No. 1141/2014 of the European Parliament and of the Council of 22 October 2014 on the statute and funding of European political parties and European political foundations', at Art. 3(1)c, Art. 6(1).

${ }^{16}$ Chancellery of the Prime Minister of Poland, 'White Paper on the Reform of the Polish Judiciary', 7 March 2018, https://www.premier.gov.pl/files/files/white_paper_en_full.pdf, para. 166.

${ }^{17}$ Iustitia (Polish Judges Association), 'Response to the White Paper Compendium on the reforms of the Polish justice system, presented by the Government of the Republic of Poland to the European Commission', 17 March 2018, https://twojsad.pl/wp-content/uploads/2018/03/iustitiaresponse-whitepaper.pdf; Gersdorf (First President of the Supreme Court), 'Opinion on the White Paper on the reform of the Polish judiciary, 16 March 2018, https://archiwumosiatynskiego.pl/ images/2018/04/Supreme-Court-Opinion-on-the-white-paper-on-the-Reform-of-the-Polish-Judi ciary.pdf. 
branch has become active. Since the lessons have been learnt from the miserable action national governments undertook against Austria in 2000, the institutional activities are so far concentrated in the Council of Europe's and the Union's institutions. The European Commission in particular tries to position itself as a defender of European values, thereby responding to the harsh criticism levelled against its earlier reluctance. In the Polish case, it has deployed two core instruments for the first time. This is significant in and of itself, as the first usage of an instrument often impacts on its further utilisation. Unfortunately, there is a clear and serious risk of failure, with a possibly calamitous impact on the European rule of law.

One instrument is the Commission's already mentioned 'Rule of Law Framework' of 2014, which was designed as an instrument whose quick implementation can avoid escalating the situation into Article 7 TEU territory. Read as an 'a maiore ad minus' approach that is permissible under Article 7(1) TEU and Article 292 TFEU, ${ }^{18}$ it provides the Commission with a procedure for engaging - through an opinion and later recommendations - in a dialogue with a Member State in case of an observed 'systemic threat to the rule of law'. To date, the use of the Framework has not yielded tangible results, which casts much doubt on the instrument's capacity to impose results. Despite several Commission's recommendations, the Polish authorities have not undertaken any remedial action and have merely made some minor concessions of an illusory nature and clearly no practical consequence.

The Commission then introduced the second instrument to show it 'meant business'. On 20 December 2017, it launched the procedure under Article 7 (1) TEU for the first time ever. It finds that there is a clear risk of a serious breach of the rule of law in Poland, indicates rather precisely which steps need to be taken, and asks that the Council recommend Poland take such steps. ${ }^{19}$ It hereby confutes a statement by its former President Barroso, who depicted Article 7 TEU as the 'nuclear option', ${ }^{20}$ a statement that evidently delegitimizes the use of this instrument. The legitimacy of its use is corroborated by the European Parliament ${ }^{21}$ as well as the Committee of the Regions, ${ }^{22}$ which support the Commission and call upon the Council to quickly follow up on the Commission's action.

The Commission's proposal merits close attention. It is detailed and extensive. It integrates the findings of other institutions, such as the Council of Europe or the

\footnotetext{
${ }^{18}$ Giegerich (2015), pp. 499, 535-536. For the opposing view, 10296/14 Legal Service of the Council, 'Commission's Communication on a new EU Framework to strengthen the rule of law: compatibility with the Treaties', 27 May 2014, http://data.consilium.europa.eu/doc/document/ST10296-2014-INIT/en/pdf.

${ }^{19}$ Supra note 2.

${ }^{20} \mathrm{SPEECH} / 13 / 684$, Barroso (President of the European Commission), 'State of the Union address 2013', 11 September 2013, http://europa.eu/rapid/press-release_SPEECH-13-684_en.htm.

${ }^{21}$ P8_TA-PROV(2018)0055, 'European Parliament resolution of 1 March 2018 on the Commission's decision to activate Article 7(1) TEU as regards the situation in Poland (2018/2541(RSP)'.

${ }^{22}$ RESOL-VI/30, 6391/18, 'Determination of a clear risk of a serious breach by Poland of rule of law - Resolution of the European Committee of the Regions of 22 February 2018'.
} 
United Nations as well as civil-society organizations. ${ }^{23}$ This fends off accusations that the findings are partisan. By demonstrating that many institutions share its findings, the Commission makes itself the voice of a broad institutional alliance. At the same time, it underlines the legal dimension of the issue by making its proposal resemble a reasoned opinion in infringement proceedings. The Commission's proposal thus evidently aims to be two things at the same time: a convincing political value judgment as well as a legally sound analysis. This is not paradoxical; rather, it corresponds to how political institutions should decide.

The legal reasoning of the Commission as to why there is a clear risk of serious breach might appear somewhat 'thin', as it does not really develop what the threshold requires. However, one needs to consider that institutional developments towards an authoritarian regime are regularly hard to grasp from a legal standpoint because legal analysis focusses on individual acts. Taken individually, such measures lend themselves more easily to justification (although most of the Polish measures against the Constitutional Tribunal seem rather clear cases). ${ }^{24}$ Indeed the Polish government tries to defend its measures through legal comparison with 'unsuspicious' countries. ${ }^{25}$ Therefore, to convincingly determine a 'clear risk of a serious breach' of an Article 2 TEU value, all Polish measures affecting the judiciary must be considered together, with due regard to the overall political and social conditions in the country. Such determination inevitably entails an important discretionary and evaluative dimension, which strictly doctrinal arguments cannot fully guide.

It is now for the Council to act, which would require the approval of four fifths of its members, i.e., 22 Member States. The Council has debated the matter in the General Affairs Council on numerous occasions, most recently in April. ${ }^{26}$ But it is distinctly possible that the Council will not decide on the matter, for instance in order to keep the Union united in difficult times (just consider Brexit!). However, such an omission could be used as an argument that the Council-and hence the Member States-do not deem the policies of the Polish government, in particular the changes to the Polish judiciary identified in the Commission's Proposal, an infringement of Article 2 TEU. Accordingly, such policies could more easily be presented as conforming to the founding values of the European Union. They could possibly even be considered an expression of the European rule of law. However, it should not be forgotten that there are also the courts. As so often in European crises, much will depend on the Court of Justice of the European Union as well as on the domestic courts-in short, on the entire judiciary in the European legal space.

\footnotetext{
${ }^{23}$ Supra note 2, para. 183 and the respective footnotes.

${ }^{24}$ Iustitia, supra note 17, p. 92; Venice Commission, 'Opinion on Amendments to the Act of 25 June 2015 on the Constitutional Tribunal of Poland', Opinion no. 833/2015, CDL-AD(2016) 001, paras. 126, 137, 138.

${ }^{25}$ 'White Paper on the Reform of the Polish Judiciary', supra note 16. But see also the rebuttal supra note 17.

${ }^{26}$ General Affairs Council, 'Rule of law in Poland', 9 April 2019: https://www.consilium.europa.eu/ media/39196/st08130-en19.pdf.
} 


\section{The Judicial Branch: 'I Love You, Like I Love Ireland'}

Contrary to the Council, courts cannot refrain from making a decision. What might help the courts is the realisation that they will be heavily criticised regardless of how they adjudicate the Polish situation. ${ }^{27}$ Still, the courts should seize any opportunity to draw red lines for the European rule of law. ${ }^{28}$ Within the complex European judicial system, it is for the CJEU to decide if Poland infringes a European value. Domestic courts should decide this issue only if the CJEU does not do so.

The CJEU might be called upon either via infringement proceedings initiated by the Commission or via preliminary-ruling requests referred to it by national courts, i.e., in top-down or bottom-up proceedings. The traditional path for judicially supervising the Member States is the infringement proceedings, the standard interaction between the two guardians of the Treaties. The infringement procedure should hence also play a vital part in the rule-of-law crisis. ${ }^{29}$ The values in Article 2 TEU are subject to the Court's jurisdiction and thus to its mandate to ensure that 'the law is observed' (Article 19(1) TEU), and the Court now seems ready to use this mandate. ${ }^{30}$ Article 7 TEU does not preclude parallel infringement proceedings, as the Van Gend en Loos precedent exemplifies. ${ }^{31}$ How to frame a possible case is more problematic; after all, the Polish situation is triggered by a combination of measures that are as diverse as they are numerous. However, the Court has already held that it can use infringement proceedings to make a finding of general and continuous deficiencies in a Member State, ${ }^{32}$ thereby overcoming its normal focus on an individual and concrete setting.

If infringement proceedings are therefore legally viable, one should nevertheless consider that it is a mighty burden for the CJEU to have to decide whether the Polish measures violate the European rule of law. However, this burden can be shared among several courts if the issue is handled via a preliminary-ruling procedure, as

\footnotetext{
${ }^{27}$ The new Vice President of the Polish Constitutional Tribunal has already stated that he would consider any CJEU decision against Poland illegitimate, Muszyński (2018).

${ }^{28}$ The Advocate General in the case indeed addresses the Polish situation. However, he does so only in terms of human rights and thereby fails to fully meet the challenge, supra note 7, para. 39.

${ }^{29}$ The Commission initiated two successfull infringement procedures based on Article 19(1) TEU and Article 47 CFR against Poland, see Case C-619/18, Commission v. Poland (Indépendance de la Cour suprême), ECLI:EU:C:2019:531 and Case C-192/18, Commission v. Poland (Indépendance des juridictions de droit commun), ECLI:EU:C:2019:924. A further infringement procedure is currently pending before the Court, see Case C-791/19, Commission v. Poland. See also the pending infringement proceedings against Hungary, Case C-66/18, Commission v. Hungary (Enseignement supérieur) and Case C-78/18, Commission v. Hungary (Transparence associative).

${ }^{30}$ Supra note 8 . In the infringement proceedings against Hungary concerning judicial independence, (Case C-286/12, Commission v. Hungary, ECLI:EU:C:2012:687) the Commission and the Court were criticized for framing and deciding the case on the grounds of discrimination rather than Article 2 TEU, Halmai (2017), p. 471.

${ }^{31}$ Case C-26/62, Van Gend en Loos v. Administratie der Belastingen, ECLI:EU:C:1963:1. In detail, Scheppele (2016), p. 105.

${ }^{32}$ Case C-494/01, Commission v. Ireland, ECLI:EU:C:2005:250, para. 36.
} 
the CJEU then responds to the concerns of national courts. Deciding the issue in a preliminary-ruling procedure would also continue the European tradition that most decisions of deep constitutional impact are taken in the European Gerichtsverbund, the European union of courts. Indeed, the $L M^{33}$ case, which was referred to the CJEU by the Irish High Court, is a first example. As the vivid Polish reactions to this referral show ${ }^{34}$ it has the potential to become a landmark decision on the issue.

The $L M$ case originates from a negative appraisal made by the Irish judicial authority as regards the rule of law in Poland. In other terms, it has its origins in a country with which Poland has always had a special relationship. A big hit of Polish rock music of the 1990s, with the title 'I love you, like I love Ireland', is a perfect example of that relationship. As the main vocalist of the group 'Kobranocka' affirmed, 'Ireland [...] had a similar history, just like us they fought for independence. We loved them for that. I loved them and love them to this day. ${ }^{, 35}$ In Polish, to 'love somebody like Ireland' means to love someone deeply. Apart from this curious note, the referral in the $L M$ case demonstrates, in broader terms, that it is inevitable that national courts become involved to vindicate the rule of law in the European legal space. ${ }^{36}$

The concrete problem addressed in the preliminary reference was whether Ireland may refuse to surrender a Polish citizen to Poland following a European arrest warrant (EAW) because of a systemic deficiency in the rule of law in that Member State. More specifically, through its referral, the Irish High Court asked the CJEU to interpret Article 1(3) of the EAW Framework Decision, which lays down the obligation to comply with fundamental rights when executing a European arrest warrant. ${ }^{37}$ In formulating its questions, the referring court made clear that, in its opinion, the recent reforms of the Polish judiciary jeopardize some fundamental values, such as 'the independence of the judiciary and respect for the Constitution', and amount to 'systemic breaches of the rule of law' as well as 'fundamental defects in the system of justice, ${ }^{38}$ thereby prospecting a real risk for the protection of the individual's fundamental right to a fair trial. In the circumstances, instead of asking the CJEU to assess the compatibility of the Polish reforms with the European rule of

\footnotetext{
${ }^{33}$ Supra note 8.

${ }^{34}$ See in this respect the statement of the Association of Judges of Ireland in defence of the referring judge https://aji.ie/communications/press-release-2018-03-15/.

${ }^{35}$ Interview with the leader of 'Kobranocka', Andrzej Kraiński, http://gazetapraca.pl/gazetapraca/ 1,68946,3425292.html (in Polish only).

${ }^{36}$ Canor (2013), p. 383.

${ }^{37}$ O.J. 2002, L 190/1 'Council Framework Decision 2002/584/JHA of 13 June 2002 on the European arrest warrant and the surrender procedures between Member States' as amended by O.J. 2009, L81/24, 'Council Framework Decision 2009/299/JHA amending Framework Decisions 2002/584/JHA, 2005/214/JHA, 2006/783/JHA, 2008/909/JHA and 2008/947/JHA, thereby enhancing the procedural rights of persons and fostering the application of the principle of mutual recognition to decisions rendered in the absence of the person concerned at the trial'.

${ }^{38}$ Joined Cases C-404/15 and C-659/15 PPU, Aranyosi and Căldăraru, ECLI:EU:C:2016:198, para. 140 .
} 
law, the Irish court asked whether, in situations akin to those in the case pending before it, judicial authorities can refrain from executing a EAW or whether, similarly to how decided in the Aranyosi and Căldăraru judgment, they need to carry out a specific and precise assessment as to the exposure of the individual concerned to the risk of unfair trial.

It is worth recalling that, in the Aranyosi and Căldăraru judgment, the CJEU had been asked to decide on the possibility for national judges to derogate from the principles of mutual recognition and mutual trust in case of alleged violations of human rights in the Member State issuing a EAW. More specifically, the referring judge had asked the Court whether, to the extent that national judicial authorities possess 'solid evidence' that detention conditions in the issuing Member State are incompatible with fundamental rights, they may or must refuse to execute a European arrest warrant. According to the CJEU, an interpretation of the EAW Framework Decision, which takes into account the absolute prohibition of inhuman or degrading treatment or punishment as set out in Article 4 CFR, implies the obligation for the national judicial authorities not to execute a EAW. However, such a decision can be taken only if 'there are substantial grounds to believe that, following the surrender of that person to the issuing Member State, he will run a real risk of being subject in that Member State to inhuman or degrading treatment'.

In other words, national judicial authorities must run a two-phase test. For starters, they need to assess whether there are systemic or generalised deficiencies as regards the detention conditions in the prison system of the issuing Member State. This appraisal must rely on 'information that is objective, reliable, specific and properly updated', including — but not limited to- 'judgments of the ECtHR, judgments of courts of the issuing Member State, and also decisions, reports and other documents produced by bodies of the Council of Europe or under the aegis of the UN'. Then, national judicial authorities must 'make a further assessment, specific and precise, of whether there are substantial grounds to believe that the individual concerned will be exposed to that risk because of the conditions for his detention envisaged in the issuing Member State'. To carry out this assessment, the executing judicial authority must ask the issuing Member State for all necessary supplementary information, as provided for by Article 15(2) of the EAW Framework Decision.

Now, in the $L M$ case, the Irish High Court submitted two questions to the CJEU. First of all, it asked whether, in the presence of cogent evidence of systemic violations of the rule of law in the issuing Member States, the executing judicial authority is in fact obliged to carry out a two-phase test similar to that devised in the Aranyosi and Căldăraru judgment. If so, the second question was if the executing judicial authority is to revert to the issuing judicial authority for any further necessary information and, as a result, 'what guarantees as to fair trial would be required'.

After summarising the facts underlying the request for a preliminary ruling and the objectives and principles governing the EAW Framework Decision, the CJEU affirmed that, according to settled case-law (i.e. Opinion 2/13 and Aranyosi and Căldăraru), the principles of mutual recognition and mutual trust among Member States can be abridged only 'in exceptional circumstances'. However, unlike the Aranyosi and Căldăraru judgment, which concerned an absolute prohibition 
(Article 4 CFR: prohibition of inhuman or degrading treatment or punishment), the $L M$ case concerned the right to a fair trial. Hence the question: does a systemic violation of the right to a fair trial amount to an 'exceptional circumstance' that may justify the abridgment of the principles of mutual recognition and mutual trust? The CJEU replied in the affirmative, stating that the independence of the judiciary is part of the essence of the fundamental right to a fair trial and that the defence of the common value of the rule of law depends, in all respects, on the effective protection of that right. Thus, in case of a real risk of violation of the right to a fair trial in the issuing Member State, the executing judicial authorities must refrain, under Article 1 (3) of the EAW Framework Decision, from surrendering the requested person.

As is clear to see, the Court did not rely on the fundamental right to a fair trial, as suggested by the Advocate General, but on the rule of law value itself. Or, to put it better: the CJEU first linked the fundamental right to a fair trial to the value of the European rule of law, and it then adopted such value as normative yardstick against which to respond to the referring court. This emerges, for instance, in paragraph 50 of the judgment, where the Court referred to Article 19 TEU as 'giv[ing] concrete expression to the value of the rule of law affirmed in Article 2 TEU' and cited the precedent in Associação Sindical dos Juizes Portugueses. As a result, due to its being a constitutional value common to the EU and its Member States, the European rule of law must be interpreted, applied and safeguarded also by national judges.

Subsequently, the CJEU affirmed that the entire surrender procedure between Member States must be carried out under judiciary supervision and that, for this to happen, national judges must be fully independent. Thus, when the requested person argues that there are systemic or generalised deficiencies which are liable to affect the independence of the judiciary in the issuing Member State, the executing judicial authority must run a two-phase test similar to that devised in the Aranyosi and Căldăraru judgment.

It first has to ascertain whether, due to systemic or generalised deficiencies connected to the independence of the judiciary in the issuing Member State, there is indeed a 'real risk' that the requested person's fundamental right to a fair trial be violated. When carrying out this assessment, the executing judicial authority must rely on 'objective, reliable, specific and properly updated' material and consider both the external and the internal dimensions of independence, notably the autonomy of the judges (i.e., the absence of any hierarchical constraint and any form of subordination vis-à-vis other powers) and their impartiality (i.e., the equal distance from the parties to the proceedings and their respective interests). Should it come to the conclusion that there indeed exists a real risk, the executing judicial authority must then assess 'specifically and precisely' whether there are 'substantial grounds' for believing that the requested person will actually run that risk. The CJEU justified the necessity of a two-phase test by referring to recital (10) of the EAW Framework Decision. According to this recital, the mechanism of the European arrest warrant can be suspended only when the Council determines, under Article 7(2) and (3) TEU, the existence of a serious and persistent breach by one of the Member States of the principles set out in Article 2 TEU. Thus, lacking such a determination by the Council, national authorities may refrain from executing a EAW only after 
carrying out an individual and specific assessment of the concrete risks faced by the person concerned.

\section{From the Maastricht Urteil to the LM Case}

Despite the generic nature of the preliminary questions put forth by the Irish judge, the CJEU did not miss out on the opportunity to make some specific considerations on the rule of law crisis in Poland and to draw some red lines. Different reasons spoke in favour of an intervention of the Court. To begin with, it was important that these red lines were drawn in a process that itself respected these European founding values, including the right to a fair hearing. Therefore, Poland had to be granted a formal role in the proceedings and be represented by its legitimate government. A domestic court could have hardly provided for that. Second, given that the recent reforms in Poland encroach significantly on the independence of judges and that - as stated in paragraph 54 of the judgment - such independence is 'essential to the proper working of the judicial cooperation system embodied by the preliminary ruling mechanism', the dispute before the Irish High Court presented such a connection with EU law as to justify the intervention of the Court. Third, and more generally, a systemic rule of law problem with judicial independence impinges on the effectiveness of the entire EU legal system; thus, an overall European assessment of the matter was necessary.

That said, one could arguably maintain that the judgment in re $L M$ is too abstract. We disagree with this argument. For instance, when explaining the first stage of the two-phase test, the Court specifies that, to assess the existence of a real risk for the rule of law value in a Member State, the executing judicial authority can rely, among other things, on the information laid down in a reasoned proposal by the Commission under Article 7(1) TEU. These acts are, according to the Court, of particular relevance for the purposes of that assessment, especially if they refer to judgments or opinions by other European and international institutions, like in the case of Poland (e.g. the United Nations Human Rights Committee, the European Council, the ECtHR, the Venice Commission etc.). This increases the soundness and legitimacy of the Commission's and, by extension, of the executing authority's findings. Moreover, as regards the disciplinary chamber mentioned in the introduction, the CJEU takes a clear stance against its compatibility with the European value of the rule of law. Finally, within the limits allowed by the specific case, the Court provides national judges with a range of criteria to be followed when carrying out the second stage of the two-phase test. The executing authorities must in fact consider the personal situation, as well as the nature of the offence for which the requested person is being prosecuted and the factual context that form the basis of the European arrest warrant.

Now, from a broader perspective, the judgment in $L M$ has (at least) two distinguishing features. First, it involves overcoming the notion that the defence of the European common values is an exclusive preserve of the European political 
institutions under Article 7 TEU. Second, it posits a pivotal role of the individuals in the protection of the European rule of law value.

As for the first feature, the Court makes clear that the defence of the European common values is also a task for the courts, especially national courts. Consistently with its role in the preliminary ruling procedure, the CJEU does not express a conclusive opinion on the Polish reforms of the judicial system. Rather, it lets the referring court decide if — and to what extent — these reforms amount to a violation of the European rule of law value. For any such decision requires much legitimacy and is likely to be highly contested, it seems wise to share this burden among several courts, national and supranational. In that respect, one might criticize the initial 'if' in paragraph 68 of the judgment for leaving that difficult task too much on the shoulders of the national judge. After all, the formulation 'systemic and generalised deficiencies' is, for all intents and purposes, a European concept, which calls for a more incisive intervention of the CJEU.

As regards the second feature, an increased involvement of national courts implies, by extension, the empowerment of individuals in the protection of the European rule of law value. By linking this value to the essence of the fundamental right to a fair trial, the Court makes a doctrinal move similar to the one the German Federal Constitutional Court undertook in its Maastricht decision. It remains to be seen if the CJEU thereby aims at a similar position as the German court in framing the founding principles of the polity. What is clear, however, is that, from here on, 'the vigilance of the individual' is core not only for the 'supervision' of European law, as famously stated by the Court in Van Gend en Loos, but also of the European rule of law value. In addition, upon jointly reading the Court's judgments in $L M$ and in Associação Sindical dos Juizes Portugueses, it clearly emerges that the European rule of law value can be used as a weapon by the very same judges whose independence is at stake. The recent request for a preliminary ruling of the Polish Supreme court bear witness to that.

At this point, the next question is what impact the $L M$ judgment will have in the overall context of the rule of law crisis management. We believe that the impact of this judgment will be colossal and will by far exceed that of the N.S. ${ }^{39}$ or the Aranyosi case. ${ }^{40}$ These two latter cases dealt with a particular violation of a certain human right under specific circumstances. The $L M$ case, by contrast, deals with a comprehensive violation of the value of the rule of law. It is about a Member State suffering from a systemic deficiency in upholding the rule of law, because the independence of the judiciary has been undermined. That could have the broadest implications and could possibly affect the fundamental principle of mutual trust on which the entire judicial cooperation in the European legal space rests. Not only will criminals not be surrendered on the basis of an EAW but asylum seekers will not be transferred on the basis of the Dublin mechanism; moreover, civil judgments

\footnotetext{
${ }^{39}$ Joined Cases C-411/10 and C-493/10, N.S. and Others v. Secretary of State for the Home Department, ECLI:EU:C:2011:865.

${ }^{40}$ Supra note 38 .
} 
originating from this state will possibly not be enforced by the national courts of all the other States.

By significantly reducing horizontal judicial cooperation, the $L M$ case could therefore isolate Poland within the European legal space, although hopefully only temporarily. This is a harsh consequence, but a number of reasons speak for it. The respect of the rule of law value is a precondition for membership (Article 49 TEU), for mutual trust, ${ }^{41}$ for all fundamental rights, for the entire European edifice. ${ }^{42}$ If that is not enough: the future of the European rule of law, as Europe thought it knows it, is at stake if no one opposes the developments in Poland. All this would justify significantly reducing horizontal cooperation with Poland.

At the same time, this solution does not foreclose vertical cooperation, as it allows national courts to continue using the preliminary-ruling procedure. This is particularly important, because the CJEU and valiant Polish courts can thereby continue to fight jointly for the European rule of law or the rights of Union citizens. ${ }^{43}$ In other words, the fact that the independence of the Polish judiciary as a system is compromised does not exclude recognizing the independence of individual courts.

The different functional logic of the preliminary ruling procedure, on the one hand, and horizontal judicial cooperation, on the other hand, allows for this distinction. In a preliminary ruling procedure, the CJEU can assess the referring court in light of its case law on judicial independence, a review that is more difficult in the case of horizontal cooperation. Moreover, the CJEU merely interprets EU law in a preliminary ruling procedure, leaving the national court to apply it to the facts, whereas horizontal judicial cooperation directly affects individuals: while horizontal cooperation subjects an individual to the authority of another Member State, a preliminary ruling procedure can in fact help an individual vis-à-vis the authority to which he or she is already subjected.

This leads to the critical issue of the threshold for non-cooperation. In the $L M$ case, the Court decided to follow the approach devised in its Aranyosi case-law. ${ }^{44}$ Accordingly, non-cooperation requires 'substantial grounds to believe' that the requested person's right to a fair trial 'will run a real risk', for which there is no evidence in the $L M$ proceedings. This choice, however, appears inadequate to tackle the rule of law crisis in Poland. Since the Polish government's measures undermine the independence of the entire judiciary, there is little or no point in conducting an individual and specific assessment of the concrete risks the person concerned faces. As things stand, there is always the danger that any case might at some point come before a compromised judge. This circumstance should have prompted the Court to

\footnotetext{
${ }^{41}$ CJEU, Opinion 2/13, Opinion on the Draft Agreement on the Accession of the European Union to the Convention for the Protection of Human Rights and Fundamental Freedoms, ECLI:EU: C:2014:2454, para 168.

${ }^{42}$ Supra note 8 , paras. 41 and 43 .

${ }^{43}$ In detail, von Bogdandy et al. (2012), p. 489.

${ }^{44}$ Supra note 7 , para. 5 .
} 
follow the test developed in N.S., ${ }^{45}$ according to which the abstract risk for the individual concerned should suffice to refuse a surrender. From a systemic standpoint, the refusal to surrender on the basis of a merely abstract risk is justified by the urgent need for red lines. From a practical perspective, it is difficult to imagine how the 'dialogue' on judicial independence between the executing authority, on the one hand, and the issuing judicial authority and its government, on the other hand, can meaningfully take place. At the same time, it is clear that once a systemic deficiency has been established, the burden of proof shifts to the country issuing the EAW. In dubio pro libertate.

\section{Conclusion}

For more than two decades, the constitutional developments in Central and Eastern European countries were mainly considered a constitutional sideshow, that depicted countries 'catching up' with their luckier neighbours who had never suffered Soviet occupation. Now, these countries stand in the limelight: much of the future path of European constitutionalism depends on how their peoples decide.

The rest of Europe cannot do a great deal for those countries' constitutionalism. One cannot expect from the deployment of the instruments analysed in this chapter a 'solution' to the crisis. None but the citizens of those countries themselves can restore the separation of powers among their countries' institutions. The decisions taken by EU institutions can only contribute 'to creating a situation where selfhealing through domestic processes is still possible'. ${ }^{46}$

However, one needs to look beyond those countries to understand the importance of using these instruments now. European decisions confronting the Polish Government are crucial to uphold a liberal and democratic self-understanding of European constitutionalism throughout Europe. Otherwise, the current Polish undermining of the independence of its judiciary is likely to count towards defining the European rule of law, facilitating similar developments in other places and compromising large parts of European foreign policy. Much is at stake. Yet, as the Polish anthem goes, 'Poland Is Not Yet Lost'; and nor is the constitutional European project, if the institutions act wisely.

\section{References}

Ackerman B (1991) We the people: foundations, vol 1, 6. Harvard University Press, Cambridge Bonelli M (2017) From a community of law to a Union of values. Eur Const Law Rev 13:793-816

\footnotetext{
${ }^{45}$ Supra note 39.

${ }^{46}$ Sonnevend (2017), pp. 123, 145.
} 
Canor I (2013) My brother's keeper? Horizontal Solange: 'An ever closer distrust among the peoples of Europe'. Common Mark Law Rev 50:383-421

Charlemagne (2018) The EU is tolerating - and enabling - authoritarian kleptocracy in Hungary. The Economist, April 5

Editorial Comments (2015) Safeguarding EU values in the Member States - is something finally happening? Common Mark Law Rev 52:619-628

Editorial Comments (2016) The rule of law in the Union, the rule of Union law and the rule of law by the Union: three interrelated problems. Common Mark Law Rev 53:597-605

Editorial Comments (2017) About Brexit negotiations and enforcement action against Poland: the EU's own song of ice and fire. Common Mark Law Rev 54:1309-1317

Giegerich T (2015) Verfassungshomogenität, Verfassungsautonomie und Verfassungsaufsicht in der EU: Zum 'neuen Rechtsstaatsmechanismus' der Europäischen Kommission. In: Calliess C (ed) Herausforderungen an Staat und Verfassung: Liber Amicorum für Torsten Stein zum 70. Geburtstag. Nomos, Baden-Baden, pp 499, 535-536

Halmai G (2017) The early retirement age of the Hungarian judges. In: Nicola F, Davies B (eds) EU law stories. Cambridge University Press, New York, pp 471-488

Halmai G (2018) Illiberal constitutionalism? The Hungarian constitution in a European perspective. In: Kadelbach S (ed) Verfassungskrisen in der Europäischen Union. Nomos, Baden-Baden, pp 85-104

Klarman MJ (1992) Constitutional fact/constitutional fiction: a critique of Bruce Ackerman's theory of constitutional moments. Stanford Law Rev 44:759-797

Matczak M (2018) 10 Facts on Poland for the Consideration of the European Court of Justice. VerfBlog, 13 May 2018. https://verfassungsblog.de/10-facts-on-poland-for-the-considerationof-the-european-court-of-justice/

Muszyński M (2018) Polski Trybunał w unijnej rzeczywistości. http://www.rp.pl/Opinie/ 303229983-Polski-Trybunal-w-unijnej-rzeczywistosci\%2D\%2D-Mariusz-Muszynski-o-mocywyrokow-TSUE-w-Polsce.html (in Polish only)

Scheppele KL (2016) Enforcing the basic principles of EU law through systemic infringement actions. In: Closa C, Kochenov D (eds) Reinforcing rule of law oversight in the European Union. Cambridge University Press, Cambridge, pp 105-132

Sonnevend P (2017) Preserving the acquis of transformative constitutionalism in times of constitutional crisis: lessons from the Hungarian case. In: von Bogdandy A, Ferrer Mac-Gregor E, Morales Antoniazzi M, Piovesan F (eds) Transformative constitutionalism in Latin America. Oxford University Press, Oxford, pp 123, 145

von Bogdandy A, Kottmann M, Antpöhler C, Dickschen J, Hentrei S, Smrkol M (2012) Reverse Solange - protecting the essence of fundamental rights against EU Member States. Common Mark Law Rev 49:489-519

Armin von Bogdandy is Director at the Max Planck Institute for Comparative Public Law and International Law, Heidelberg.

Piotr Bogdanowicz is Assistant Professor, Faculty of Law and Administration, Warsaw University.

Iris Canor is Professor, School of Law, Zefat Academic College, Israel; School of Law, College of Management, Israel.

Giacomo Rugge is Research Fellow, Max Planck Institute for Comparative Public Law and International Law, Heidelberg.

Matthias Schmidt is Research Fellow, Max Planck Institute for Comparative Public Law and International Law, Heidelberg. 
Maciej Taborowski is Assistant Professor, Faculty of Law and Administration, Warsaw University.

Open Access This chapter is licensed under the terms of the Creative Commons Attribution 4.0 International License (http://creativecommons.org/licenses/by/4.0/), which permits use, sharing, adaptation, distribution and reproduction in any medium or format, as long as you give appropriate credit to the original author(s) and the source, provide a link to the Creative Commons license and indicate if changes were made.

The images or other third party material in this chapter are included in the chapter's Creative Commons license, unless indicated otherwise in a credit line to the material. If material is not included in the chapter's Creative Commons license and your intended use is not permitted by statutory regulation or exceeds the permitted use, you will need to obtain permission directly from the copyright holder.

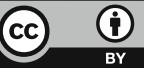

